УДК 81'373.612.2-31

DOI: 10.32403/978-966-322-528-9-2021-185-188

Kateryna Raznorovich

Academic adviser: Olga Rusak

\title{
METAPHORIZATION IN THE NOVEL \\ BY A. S. PUSHKIN «EUGENE ONEGIN» AND ITS TRANSLATION INTO BELARUSIAN
}

The paper analyzes the metaphorical images presented in the Belarusian-language translation of the novel "Eugene Onegin», prepared by A. Kuleshov. The comparison of metaphors and metaphorical epithets of the original and the translation allowed us to distinguish the following types of correspondences-inconsistencies between them: semantically equivalent means, the most approximate variant figurative means, demetaphorization of the author's image.

Key words: literary translation, translation of figurative means, metaphor, metaphorical epithet, translation transformations, demetaphorization.

Катерина Разноровіч

Науковий керівник: Ольга Русак

\section{МЕТАФОРИЗАЦІЯ В РОМАНІ А. С. ПУШКІНА «ЄВГЕНІЙ ОНЄГІН» \\ І ЙОГО ПЕРЕКЛАДІ НА БІЛОРУСЬКУ МОВУ}

У роботі проаналізовано метафоричні образи, представлені в білоруськомовному перекладі роману «Євгеній Онєгін», підготовленому А. Кулешовим. Зіставлення метафор і метафоричних епітетів оригіналу і перекладу дозволило виділити такі види відповідностей-невідповідностей між ними: семантично еквівалентні засоби, максимально наближені варіантні образні засоби, деметафоризація авторського образу. 
Ключові слова: художній переклад, переклад образних засобів, метафора, метафоричний епітет, перекладацькі трансформації, деметафоризація.

One of the urgent problems of modern philological science is the study of linguistic aspects of interlanguage speech activity. Translation of a literary text is a complex process that requires taking into account the rhythmic and intonational features of the work, the extraordinary author's associations, the cultural subtleties of the era in which the writer lived and worked, and much more.

The purpose of this work is to analyze the metaphorical images of A. S. Pushkin's novel «Eugene Onegin» translated into Belarusian by A. Kuleshov.

A metaphor (from the ancient Greek, $\mu \varepsilon \tau \alpha \varphi \rho \rho \alpha$ «hyphenation») is a word or expression used in a figurative sense; the metaphor is based on a comparison of an unnamed object with some other on the basis of their common feature (similarity of appearance, forms, characteristics, etc.).

Since the variants of the translation of Pushkin's figurative means into the Belarusian language are diverse, the comparison of metaphors and metaphorical epithets of the original and the translation allowed us to distinguish several types of correspondences-inconsistencies between them.

First, semantically equivalent figurative means are quite common, because A. Kuleshov tried to preserve the artistic value of Pushkin's metaphors: Огнём нежданных эпиграм - Агнём раптоўных эпіграм; Партер и кресла, все кипит Партэр і крэслы - усё кіпіць; Желаний своевольный рой - Жаданняў, парыванняў рой; Розы пламенных ланит - Ружы полымных ланіт; Кипит воображенье - Зноў уяўленне закіпае; И вод веселое стекло - Вада вясёлым ззяе шклом; Узрю ли русской Терпсихоры душой исполненный полет - Ці уббачу рускай Тэрпсіхоры палёт, што выканан з душой? 
Pushkin often uses such a kind of metaphor as personification - the transfer of signs of living beings to inanimate objects. As a rule, in the Belarusian translation, the impersonation is preserved: $И$, устремив на чуждый свет $\mathbf{P a -}$ зочарованный лорнет - I на чужы навёўшы свет Расчараваны свой ларнет; Сонная улица - Санлівай вуліцы спакой; Рев скрипок - Скрыпак дружны хор; Дыханье ночи - Начы прыемны подых; Перо, забывшись, не рисует - Пяро міжволі не малюе; Проснулся утра шум приятный - Прачнуўся дзень прыемны, новы.

Secondly, Kuleshov introduced a variant image as close to the original as possible, since it was not possible to preserve semantics everywhere: Душа воспламенилась в нём - Пачуцці закіпелі ў ім; В обоих сердца жар угас - Агонь у нашых сэрцах згас; Морозной пылью серебрится Его бобровый воротник - И срэбрам ззяе Снег на бабровым каўняры; Змея воспоминаний - Гадзюка ўспамінаў. As we can see from the examples, in translation, the metaphors differ from the original ones, but this does not significantly change the author's images.

Third, linguistic difficulties in some cases did not allow us to convey the original images, so they are lost. This phenomenon is called demetaphorization - the loss of the figurative component of the metaphor in the translated text, the translator's refusal to use the trope: Его тоскующая лень - Яго ляноты кожны дзень; Лишь лодка, веслами махая, Плыла по дремлющей реке - I лодку, што навідавоку, Паволі несла ўдаль рака. In the original novel, metaphorical epithets are used (тоскующая лень, дремлющая река), which characterize the state of living beings, and therefore there is an impersonation. In translation, this element of semantics is not transmitted, which impoverishes the images.

Taking into account the subtleties of the author's images, the transfer of the plot and the features of the composition, the atmosphere of the insight and the writer's idea - this is a necessary work on a high-quality artistic translation. The 
preservation and replacement of Pushkin's metaphors are organic and justified in the translation of A. Kuleshov, since he used a creative approach. One of the main tasks of the translator is to preserve the original volume of semantics. The peculiarities of the Belarusian and Russian languages did not allow to transmit the original text verbatim, but at the same time contributed to the high-quality processing of figurative means. To do this, Kuleshov resorted to the transformation of the author's images, tried to compensate for the destruction of metaphors by introducing other linguistic means. 